chemists for a variety of reasons, such as an interest in the light stability of dyestuffs, eatalytic properties of conjugated compounds, or properties of polycyclic aromatic compounds in relationship to coal. 'I he workers lent heavily on the broad theoretical ideas of the physicists, and still do. Tho physicists found germanium hard enough to understand, without branching out to consider organic substances, principally of ill detined purity. The additional stimulus of Szent-Gyorgyi's speculation on biochemical mechanisms in 1942 led to work on proteins and nucleic acids, and these biological aspects were first discussed at a Faraday Discussion at Nottingham in 1959. Around 1956 the relatively high conductivity of erystals of organic charge transfer complexes was discovered. An extra stimulus came in about 1960 when the Russian work on the semiconducting properties of heat-treated polyacrylonitrile appeared, and a great spate of work followed on polymers, of varying degrees of defined structure and purity. About this time also, precision pulse photoeonduction measurements started on zone-refined anthracene and similar compounds. As a result of this work a good deal is now known about the way the various molecular energy states are involved in anthracene photoconduction, the effects of adsorbed oxygen and so on. Although a number of patents have been taken out in the field, many referring to electrophotography and one to possible superconduction, a major practical achievement is still awaited. On the biological side there are now a good many suggestions as to the involvement of electronic conduction in a number of biological processes, from photosynthesis to bone growth. without any conclusive proofs so far. (A discussion on the biological properties is planned for Nottingham in April 1968.)

With so much initial activity complete, we must extend a particular welcome to the present volume, by two Australian authors well known in the field. The treatment is as comprehensive as possible, and covers all the available literature, to the end of 1965; I detected only one or two gaps, in the Russian and Chinese references. An initial chapter outlines the basic notion of solid state physics which underlies the field of activity. Then follows an account of experimental methods and sample preparation. A fourth chapter deals with "Band Theory in Molecular Crystals", a fifth with excited states, and a sixth with ionized states. Finally, the tunnelling and hopping models are considered, the published data reviewed, parallels drawn between semiconductivity and structure, and the effect of space charges outlined. A last chapter comprises "Retrospect, Outlook and Speculation", and summarizes the present state of the art.

The book is to be praised for the comprehensive and accurate fashion in which it summarizes experiments and discusses theories. The account is well balanced as well as encyclopaedic in character. No attempt is made critically to evaluate and distinguish the different approaches, and it may be argued that it is still too early for this to be a fruitful process. So far as can be judged the tables of data are reliable at all points. This is a book for all who contemplate research in the field. The authors deserve praise for their great effort of compilation, and the result is strongly recommended.

D. D. ETEY

\section{CARBONATE ROCKS}

\section{Carbonate Rocks}

Origin, Occurrence and Classification. Edited by George V. Chilingar, Harold J. Bissell and Rhodos W. Fairbridge. (Developments in Sedimentology, 9A.) Pp. 471. (Amsterdam, London and New York: Elsevier Publishing Company, 1967.) $150 s$.

ThIs volume, together with Volume $9 \mathrm{~B}$ in this series, is designed to provide an overall treatment of carbonates.
Almost half (177 pages) of the book is devoted to two papers under the joint authorship of G. M. Friedman and J. E. Sanders ("Origin and Occurrence of Limestones" and "Origin and Occurrence of Dolostones"). Together these provide a valuable survey of much recent work within the area of reference. Some information is drawn from the author's' own experionce (published and unpublished). kut reforence to 741 papers, fiom Furopean, American ard other sources, some of which are comparatively inaccessible, is an indication of their familiarity with, and presentation of, a very large volume of literature.

The same cannot be said of some other contributions. Fewer works are referred to by Y. Gubler, J. P. Bertrand, L. Mattavelli, A. Rizzini and R. Passega ("Petrology and Petrography of Carbonate Rocks"); due acknow. ledgement is not given to the domirant American influences on contemporary thought (economic and academic) in this area.

A different criticism might be levelled at $\mathbf{H}$. J. Bissell and G. V. Chilingar ("Classification of Sedimentary Carbonate Rocks"). The authors display a commendable lack of partiality, but a more systematic approach, such as that in one of the recent reviews of carbonate classification which they themselves recorrmend, would have been desirable. The new system proposed is not a radical departure, and is unlikely to meet with wide support. The article is nevertheless necessary to the volume and the authors provide many references and pertinent comments.

Other contributions by W. H. Taft ("Modern Carbonate Sediments") and J. W. Harbaugh ("Carbonate Oil Reservoir Rocks") also provide useful summaries. Harbaugh emphasizes the increasing commercial importance of both the physical-petrological and biological-ecological approaches to roservoir evaluation, and the interdependence of such factors with the environmental conditions in which the rocks were depositcd.

"Carbonate Rocks and Palaeoclimatology in the Biochemical History of the Planet" (R. W. Fairbridge) is concerned with the wider implications of carbonate sediments and onvironments. The geochemical, custatic and tectonic controls of carbonate sediments make them an exceptionally interesting field for large scalo geological speculation.

In some ways the book is a disappointment: chapters are not all of the same standard, plates are not always relevant, and the introduction reviews at too great a length the subsequent chapters, themselves reviews. The surveys (particularly those by Friedman and Sanders) and references contained in them are, however, likely to prove of continuing use to the specialist and to those seeking a more general background to the ever-growing literature.

C. J. R. Braithwatte

\section{SUBJECTIVE TIME}

\section{Psychological Time in Health and Disease}

By John Cohen. (A Monograph in American Lectures in Living Chomistry.) Pp. $\mathrm{xv}+103$. (Springfield, Ill. Charles C. Thomas, Publishers, 1967.) $\$ 6.50$.

THE relationship between psychological time and physical or clock time has been the subject of philosophical speculation for many centuries. The study was put on a more scientific footing by the early experimental psychologists. but the area has been curiously neglected for the past 50 years. Profossor Cohen's monograph may thus serve as a useful introduction to the psychology of time perception, either for those who are interested to discover what kind of work has been done or for those who are contem. plating carrying out work in the aroa.

There is mounting evidence that many biological rhythms are controlled by internal "clocks" or "pacemakers" and, in his first chapter, Cohen examines the 